\title{
Cationic Protein-induced Sensory Nerve Activation: Role of Substance P in Airway Hyperresponsiveness and Plasma Protein Extravasation
}

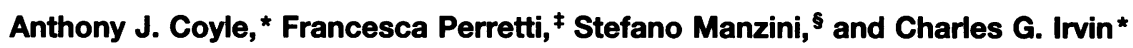

*Division of Pulmonary Sciences, Department of Medicine, University of Colorado Health Science Center and National Jewish Center for Immunology and Respiratory Medicine, Denver, Colorado 80206; ${ }^{\ddagger}$ Malesci Pharmaceuticals, Firenze, Italy; and ${ }^{\S}$ Menarini Ricerche Sud. 00040 Pomezia, Rome, Italy

\begin{abstract}
We have previously reported that human eosinophil granule major basic protein and synthetic cationic proteins such as poly-L-arginine and poly-L-lysine, can increase airway responsiveness in vivo. In the present study, we have investigated whether activation of sensory C-fibers is important in this phenomenon. Dose-response curves to methacholine were constructed before and $1 \mathrm{~h}$ after intratracheal instillation of poly-L-lysine in anaesthetized spontaneously breathing rats, and the concentration of methacholine required to induce a doubling in total lung resistance was calculated. Poly-L-lysine induced a fivefold increase in airway responsiveness, which was inhibited by neonatal capsaicin treatment and potentiated by phosphoramidon $(100 \mu \mathrm{g} / \mathrm{ml})$. Furthermore, pretreatment with either CP, 96-345, or RP67580 two selective NK-1 receptor antagonists inhibited poly-L-lysine-induced airway hyperresponsiveness and plasma protein extravasation. In vitro, cationic proteins stimulated the release of calcitonin gene-related peptidelike immunoreactivity from perfused slices of the main bronchi. Our results demonstrate that cationic proteins can activate sensory $C$-fibers in the airways, an effect which is important in the subsequent development of airway hyperresponsiveness and plasma protein extravasation. Cationic proteins may therefore function as a link between inflammatory cell accumulation and sensory nerve activation. $(J$. Clin. Invest. 1994. 94:2301-2306.) Key words: cationic proteins • airway hyperresponsiveness • substance P • tachykinins $\cdot$ plasma extravasation
\end{abstract}

\section{Introduction}

Substance $\mathrm{P}$ and neurokinin $\mathrm{A}$ are two small structurally related bioactive peptides, collectively referred to as tachykinins, that are stored in the peripheral terminals of primary afferent neurons of both vagal and spinal origin (1). In the airways, these peptides induce a variety of biological effects including smooth muscle constriction (2), increased vascular permeability (3), facilitation of cholinergic transmission (4), and mucus secretion (5). Therefore, it has been suggested that stimulation of sensory

Address correspondence to Anthony J. Coyle, Ph.D., Department of Allergy and Asthma, CIBA, Basel, Switzerland, CH-4002. 1994.

Received for publication 26 April 1994 and in revised form 3 August

J. Clin. Invest.

(C) The American Society for Clinical Investigation, Inc.

$0021-9738 / 94 / 12 / 2301 / 06 \quad \$ 2.00$

Volume 94, December 1994, 2301-2306 nerve endings, resulting in activation of a local axonal reflex, may play a role in the development of airway disease, such as bronchial asthma (6). This hypothesis has been supported recently by studies performed in experimental animals, demonstrating that antigen-induced airway hyperresponsiveness was inhibited by depletion of tachykinin containing nerves using the selective C-fiber neurotoxin, capsaicin (7).

The development of airway hyperresponsiveness, both in experimental animals and man, is also associated with an infiltration of eosinophils $(7,8,9)$ and the subsequent release of eosinophil-derived products $(9,10)$ such as major basic protein (MBP), ${ }^{1}$ an arginine/lysine-rich cationic protein (11). Recently, we and others have reported that MBP is able to induce airway hyperresponsiveness in vivo (12-14). While the precise mechanisms underlying this effect are unclear, we have shown previously that this effect appears to be dependent on the highly charged nature of these cationic proteins. As activation of sensory C-fibers has been suggested to be important in the development of airway hyperresponsiveness, we have investigated whether two synthetic cationic proteins, poly-L-lysine and polyL-arginine, used as paradigms of native cationic proteins, can stimulate airway sensory nerves in vitro. Furthermore, we sought to determine whether the ability of poly-L-lysine to induce airway hyperresponsiveness and plasma protein extravasation is dependent on activation of airway sensory C-fibers.

\section{Methods}

\section{Animals}

Adult Sprague Dawley rats of either sex (Sasco, Omaha, NE) weighing 240-320 g were used throughout this study.

\section{Assessment of lung function}

Rats were anaesthetised with a mixture of xylazine $(3 \mathrm{mg} / \mathrm{kg})$ and ketamine $(30 \mathrm{mg} / \mathrm{kg})$ administered intraperitoneally, and lung function was measured as described previously $(13,14)$. Briefly, animals were intubated with a 6-cm-long endotracheal tube (PE 205; Intramedic, Becton Dickinson, Parsippany, NJ) and placed in a whole body plethysmograph (Model PYLAN; Buxco Electronics, Sharon, CT). Tidal volume was monitored as differential pressure (MP45-871, $\pm 2 \mathrm{~cm} \mathrm{H}_{2} \mathrm{O}$; Validyne Engineering Corp., Northridge, $\mathrm{CA}$ ) between the main chamber and a reference chamber filled with copper gauze to control for thermal drift. A saline-filled catheter was placed in the esophagus to estimate intrapleural pressure and positioned to obtain maximal pressure swings with minimum cardiogenic artifact. Measurements of total lung

1. Abbreviations used in this paper: CGRP, calcitonin gene-related peptide; CGRP-LI, calcitonin gene-related peptide-like immunoreactivity; DIPA, distal intrapulmonary airway; MBP, major basic protein; NEP, neutral endopeptidase; PC100, provocative concentration of methacholine required to increase RL by $100 \%$; PIPA, proximal intrapulmonary airway; RL, total lung resistance; TER, total evoked release. 
resistance ( $R L)$ were calculated breath by breath at isovolume flow points using an automated respiratory mechanics analyser (Model 6; Buxco, Electronics).

\section{Determination of airway responsiveness to methacholine}

After measurement of baseline lung function, rats were exposed to an aerosol of saline for $15 \mathrm{~s}$, followed by increasing concentrations of methacholine (Sigma Chemical Co., St. Louis, MO) $(0.18-5.0 \mathrm{mg} / \mathrm{ml})$ for $15 \mathrm{~s}$ at each dose. When the response reached a plateau, animals were exposed to the next dose until there was at least a doubling in RL. The provocative concentration of methacholine required to increase RL by $100 \%$ ( $\mathrm{PC100}$ ) was calculated by linear interpolation and used as an index of airway responsiveness. Data are expressed as the geometric mean \pm geometric SEM.

\section{Instillation of poly-L-lysine}

After the resolution of the bronchoconstriction induced by methacholine (usually $15-20 \mathrm{~min}$ ), $100 \mu \mathrm{l}$ of poly-L-lysine $(1 \mathrm{mg} / \mathrm{ml})$ dissolved in saline was instilled into the airways via the endotracheal tube using a 23-gauge needle and airway responsiveness to methacholine measured $1 \mathrm{~h}$ later.

\section{Experimental Protocol}

In these experiments, we have used three separate experimental approaches to demonstrate a role of sensory nerve activation in the development of airway hyperresponsiveness following poly-L-lysine instillation.

Peptide depletion using the neurotoxin capsaicin. Rats were treated neonatally on the second day of birth, with capsaicin $(50 \mu \mathrm{g} / \mathrm{g}$, s.c.). Control animals were treated with the vehicle for capsaicin alone ( $80 \%$ saline, $10 \%$ ethanol, $10 \%$ tween). Animals were then studied 3-4 mo later (1), as described above. 4-7 animals were used in each group.

Inhibition of peptide degradation. $10 \mathrm{~min}$ before instillation of a submaximal dose of poly-L-lysine ( $30 \mu \mathrm{g}$ ), animals were exposed to either an aerosol of the neutral endopeptidase inhibitor phosphoramidon for $3 \mathrm{~min}(100 \mu \mathrm{g} / \mathrm{ml})$ or saline and airway responsiveness measured $1 \mathrm{~h}$ later. 5-7 animals were used in each group.

Selective receptor antagonism. $5 \mathrm{~min}$ before instillation of $100 \mu \mathrm{g}$ of poly-L-lysine, animals were injected intravenously with the nonpeptide selective NK-1 receptor antagonist, CP-96,345 (1-10 mg/kg), (2S,3S)-cis-2-(diphenylmethyl)-N-[(2-methoxyphenyl)-methyl]-1azabicyclo-[2.2.2] octan-3-amine (Pfizer Pharmaceutical, Inc., New York, NY) (15). Control animals were injected intravenously with saline alone, $5 \mathrm{~min}$ before poly-L-lysine. In addition, the effect of $\mathrm{CP}$ 96,345 ( $3 \mathrm{mg} / \mathrm{kg}$, i.v.) on airway responsiveness to methacholine was determined after intratracheal instillation of saline. Similarly, another group of rats were injected with RP-67580 (3 mg/kg, i.v.), (93aR, RaR)-7,7-diphenyl-2-1-imino-2(2-methoxyphenyl)ethylperhydroisoindol -4-one) (16), 5 min before challenge with poly-L-lysine, and airway responsiveness was determined $1 \mathrm{~h}$ later. Control animals received the appropriate control vehicle for RP-67580.

\section{Measurement of plasma protein extravasation}

The ability of poly-L-lysine to induce plasma protein extravasation was investigated by measurement of Evans blue leakage as described previously (17). Briefly, rats were intubated as above, and the jugular vein was cannulated. $15 \mathrm{~min}$ after intratracheal instillation of $100 \mu \mathrm{g}$ of polyL-lysine, Evans blue dye $(30 \mathrm{mg} / \mathrm{kg}$ ) was injected intravenously. $5 \mathrm{~min}$ later, the abdomen was opened, and the aorta was cut. The pulmonary artery was cannulated and the lungs perfused with $100 \mathrm{ml}$ of saline under a perfusion pressure of $100 \mathrm{~mm} \mathrm{Hg}$. The lungs were then removed, the parenchyma was gently scrapped off, and the airways were divided in tracheal, bronchial, proximal intrapulmonary airways (PIPA), and distal intrapulmonary airways (DIPA). Each airway section was weighed wet and placed in $2 \mathrm{ml}$ of $10 \%$ formamide for $24 \mathrm{~h}$ at $50^{\circ} \mathrm{C}$ to extract the dye. Absorbance was then measured at $620 \mathrm{~nm}$ and the amount of extravasation was expressed as ng dye/mg tissue. Animals

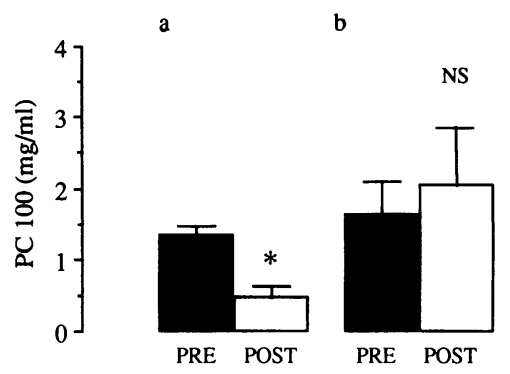

Figure 1. The effect of neonatal capsaicin treatment on poly-L-lysineinduced airway hyperresponsiveness. Airway responsiveness is shown as the geometric mean of $\mathrm{PC} 100+$ geometric SEM, before (closed columns) and $1 \mathrm{~h}$ after (open columns) instilla-

tion of poly-L-lysine in $(a)$ control animals or $(b)$ capsaicin-treated animals. * Significance was determined by a Student's $t$ test and $P$ $<0.05$ was considered significant for $n=5-7$ animals in each group. NS, not significant.

were treated with either CP-96,345 ( $3 \mathrm{mg} / \mathrm{kg}$, i.v.) or saline, $5 \mathrm{~min}$ before poly-L-lysine instillation.

\section{Peptide release experiments}

Slices taken from the main bronchi of 5-6 animals were pooled, placed in a 2-ml organ bath, maintained at $37^{\circ} \mathrm{C}$ and oxygenated with $95 \% \mathrm{O}_{2}$ and $5 \% \mathrm{CO}_{2}$. Tissues were superfused at a flow rate of $0.4 \mathrm{ml} / \mathrm{min}$ with PSS containing thiorphan $(10 \mu \mathrm{M})$. After a 30-min equilibration period, preparations were exposed to either poly-L-arginine $(10 \mu \mathrm{g} / \mathrm{ml})$ or polyL-lysine $(10 \mu \mathrm{g} / \mathrm{ml})$ for $30 \mathrm{~min}$. In some experiments, tissues were desensitized to capsaicin $(10 \mu \mathrm{M})$ during a 30 -min period, and then stimulated with either poly-L-lysine or poly-L-arginine for a further 30 min. Superfusates were collected every $5 \mathrm{~min}$ in tubes containing enough acetic acid to give a final concentration of $2 \mathrm{~N}$. At the end of the experiment, tissues were blotted three times on a filter paper and weighed. After reconstitution with the assay buffer $(0.1 \mathrm{M}, \mathrm{pH} 7.4$, phosphate buffer containing $0.1 \mathrm{~g} /$ liter $\mathrm{BSA}, 0.01 \% \mathrm{NaN}_{3}$, and $0.9 \% \mathrm{NaCl}$ ) the calcitonin gene-related peptide-like immunoreactivity (CGRP-LI) content of each fraction was measured as previously described using a rat $\alpha$ CGRP, RAS 6012 anti-CGRP rabbit antiserum (Peninsula Laboratories, Inc., Belmont, CA), and [ ${ }^{125}$ I] iodo histidyl CGRP (1). Coefficient of percentage variation was $<10 \%$ for values between 20 and $300 \mathrm{pmol} /$ liter. The lower detection limit was $2 \mathrm{fmol} /$ tube. The antiserum cross reacted $100 \%$ with rat $\beta$-CGRP and with both human CGRP-I and -II, and less than $0.1 \%$ with salmon and human calcitonin. Total peptide content in each fraction was measured and expressed in terms of pmol of CGRP-LI per mg tissue weight.

CGRP-LI outflow was evaluated in every collected sample ( $5 \mathrm{~min}$ superfusion) or as total evoked release (TER). TER represents the difference between capsaicin or cationic protein-evoked release in 30 min of superfusion and the release obtained from baseline equivalent to a same period of time.

\section{Statistical analysis}

For determination of statistical significance in the release experiments and in the responsiveness experiments, a Student's $t$ test was used, and a value of $P<0.05$ was considered significant. In the permeability experiments, ANOVA was used with a Bonferoni correction for multiple comparisons. A $P$ value of $P<0.05$ was considered significant.

\section{Results}

\section{Role of tachykinins in cationic protein-induced airway hyperresponsiveness}

Inhibition of poly-L-lysine induced airway hyperresponsiveness by capsaicin pretreatment. Intratracheal instillation of poly-Llysine increased airway responsiveness to methacholine in control animals (PC 100 PRE: $1.33 \mathrm{mg} / \mathrm{ml}(1.20-1.47)$; POST: $0.46 \mathrm{mg} / \mathrm{ml}(0.21-0.62), n=4, P<0.05)$, (Fig. $1 a)$. In 

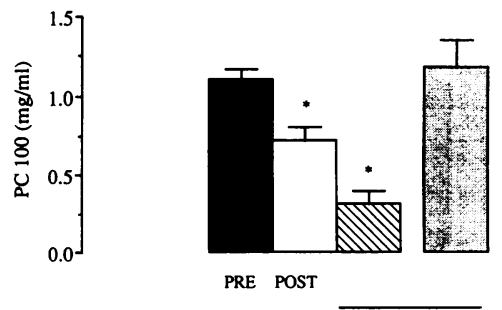

Figure 2. The effect of phosphoramidon ( 100 $\mu \mathrm{g} / \mathrm{ml})$ on poly-L-lysine-induced airway hyperresponsiveness. Airway responsiveness is shown as the geometric mean of $\mathrm{PC} 100+$ geometric SEM before (closed columns) and 1 $\mathrm{h}$ after poly-L-lysine instillation (open columns). Phosphoramidon ( $\mathrm{di}$ agonal columns) was administered by aerosol ( $100 \mu \mathrm{g} / \mathrm{ml}, 3 \mathrm{~min}) 10$ min before instillation of a submaximal concentration of poly-L-lysine. The effect of phosphoramidon alone on methacholine responsiveness is shown for comparison (shaded columns). * Significance was determined by a Student's $t$ test for nonpaired data and $p<0.05$ was considered significant for $n=6$ animals.

contrast, there was no increase in responsiveness following poly-L-lysine instillation in animals that had been pretreated with capsaicin (PC 100 PRE: $1.63 \mathrm{mg} / \mathrm{ml}$ (1.21-2.19); POST: $2.04 \mathrm{mg} / \mathrm{ml}$ (1.30-2.80), $n=7, P>0.05$ ) (Fig. $1 b$ ).

Potentiation of poly-L-lysine induced airway hyperresponsiveness by phosphoramidon. Intratracheal instillation of a submaximal dose of poly-L-lysine (13) induced a small but significant increase in airway responsiveness. Pretreatment with phosphoramidon enhanced airway responsiveness induced by polyL-lysine. Exposure to an aerosol of phosphoramidon alone failed to modify airway responsiveness to methacholine $1 \mathrm{~h}$ later (Fig. 2 ). As there was no significant difference in baseline responsiveness in the three study groups, for clarity, the PC 100 PRE value is shown as the mean baseline of the three groups.

Inhibition of poly-L-lysine induced airway hyperresponsiveness by selective NK-1 receptor antagonists. Pretreatment with CP-96,345 (1-10 mg/kg) (Fig. 3) inhibited poly-L-lysineinduced airway hyperresponsiveness. Injection of CP-96,345 (3 $\mathrm{mg} / \mathrm{kg}$ ) failed to modify methacholine-induced bronchoconstriction. The PC 100 PRE value is shown as the geometric mean of the four groups. Likewise, pretreatment with RP-67580 ( $3 \mathrm{mg} / \mathrm{kg}$ ) inhibited poly-L-lysine-induced airway hyperresponsiveness (Fig. 4). Injection of RP-67580 had no significant effect of airway responsiveness to methacholine (data not shown).

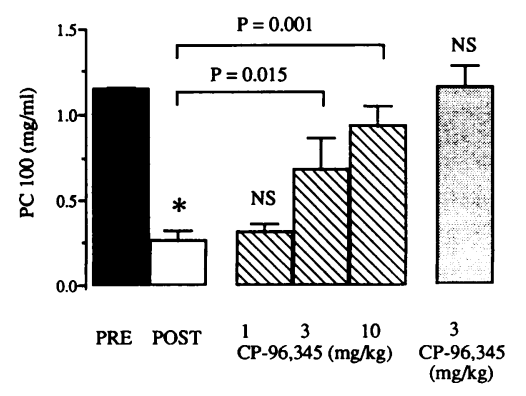

Figure 3. The effect of CP-96,345 on poly-L-lysine-induced airway hyperresponsiveness. Airway responsiveness is shown as the geometric mean of $\mathrm{PC} 100+$ geometric SEM before (closed columns) and 1 $\mathrm{h}$ after poly-L-lysine instillation (open columns). CP-96,345 (di-

agonal columns) (1-10 mg/kg i.v.) was administered $5 \mathrm{~min}$ before instillation of poly-L-lysine. The effect of CP-96,345 alone on methacholine responsiveness is shown for comparison (shaded columns). * Significance was determined by a Student's $t$ test for nonpaired data and $P<0.05$ was considered significant for $n=4-7$ animals. NS, not significant.

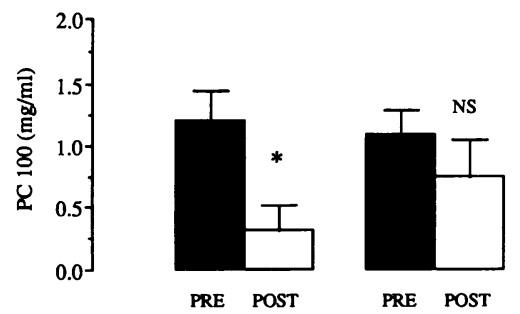

Figure 4. The effect of RP-67580 on poly-L-lysine-induced airway hyperresponsiveness. Airway responsiveness is shown as the geometric mean of $\mathrm{PC} 100+$ geometric SEM before (closed columns) and 1 $h$ after poly-L-lysine instillation (open col-

umns). Animals were treated with either $(a)$ vehicle or $(b)$ RP-67580 $(3 \mathrm{mg} / \mathrm{kg}), 5 \mathrm{~min}$ before instillation of poly-L-lysine. * Significance was determined by a Student's $t$ test for paired data and $P<0.05$ was considered significant for $n=4-5$ animals. NS, not significant.

\section{Contribution of substance $P$ to poly-L-lysine-induced plasma protein extravasation}

Instillation of poly-L-lysine into the lungs increased leakage of Evans blue dye in the trachea $(P<0.001)$, bronchi $(P$ $<0.0001)$, PIPA $(P<0.001)$ and DIPA $(P<0.01)$, compared with animals that received saline. Pretreatment with CP-96,345 ( $3 \mathrm{mg} / \mathrm{kg}$ ) inhibited leakage in the trachea by $81.2 \%(P$ $<0.0001)$, bronchi by $79.4 \%(P<0.001)$, and the PIPAs by 91.0\% $(P<0.001)$. CP-96,345 was ineffective in inhibiting leakage in the DIPA $(P=0.51)$. Injection of CP-96,345 alone had no significant effect on leakage of Evans blue at any level of the airways (Fig. 5).

\section{Sensory nerve activation induced by synthetic cationic proteins}

Superfusion of isolated bronchi with either poly-L-lysine (Fig. $6 a$ ) or poly-L-arginine (Fig. $6 b)(10 \mu \mathrm{g} / \mathrm{ml})$ stimulated the release of CGRP-LI. The TER induced by poly-L-lysine was $0.925 \pm 0.39 \mathrm{pmol} / \mathrm{g}$ wet weight per $30 \mathrm{~min}(n=4)$. This effect was rapid and occurred exclusively during the first 10-15 min of perfusion. Similarly, poly-L-arginine stimulated CGRP-LI release, which developed more slowly, but was more sustained than that observed with poly-L-lysine, and became significant $15 \mathrm{~min}$ after the beginning of cationic protein superfusion. The TER after perfusion with poly-L-arginine was $1.40 \pm 0.50 \mathrm{pmol} /$ $\mathrm{g}$ wet weight per $30 \mathrm{~min}(n=4)$. Exposure of tissues to capsaicin $(10 \mu \mathrm{M})$, induced a TER of $6.7 \pm 1.6 \mathrm{pmol} / \mathrm{g}$ wet

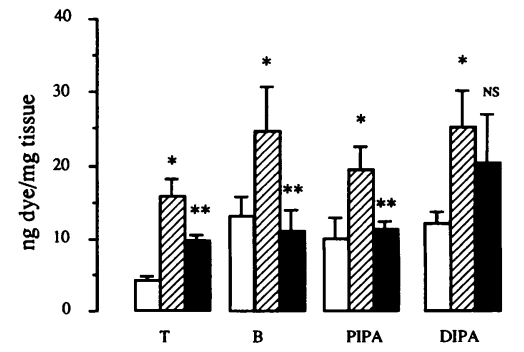

Figure 5. The effect of CP-96,345 on poly-L-lysine-induced plasma protein extravasation. Results are expressed as the mean \pm SEM of the amount of Evans blue dye (ng dye/mg tissue) in the trachea $(T)$, bronchi $(B)$, proximal $(P I P A)$, and distal

$(D I P A)$ intrapulmonary airways following instillation of either poly-Llysine (diagonal columns) or saline (open columns). CP-96,345 ( $3 \mathrm{mg} /$ $\mathrm{kg}$ ) was injected $5 \mathrm{~min}$ before poly-L-lysine instillation (shaded columns). Statistical significance from saline-treated animals $(*)$ or from poly-L-lysine-treated animals $(* *)$ was determined by a nonpaired Student's test with Bonferoni correction for multiple comparisons and a value of $P<0.05$ was considered significant. NS, not significant. 


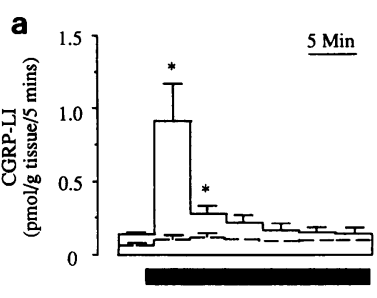

$10 \mu \mathrm{g} / \mathrm{ml}$ poly-L-lysine

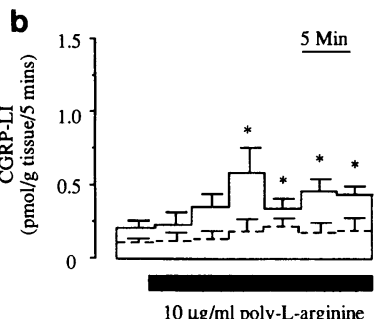

$10 \mu \mathrm{g} / \mathrm{ml}$ poly-L-arginine

Figure 6. Release of CGRP-LI before and during exposure to ( $a$ ) polyL-lysine or $(b)$ poly-L-arginine. Each column represents a collection period of $5 \mathrm{~min}$ in control tissues (solid lines, $n=4$ ) and capsaicin desensitized tissues (dotted lines, $n=4)$. * Significance was determined by a Student's $t$ test for paired data and $P<0.05$ was considered significant.

weight $(n=8)$. Pretreatment with capsaicin inhibited poly-Llysine (TER: $0.14 \pm 0.02 \mathrm{pmol} / \mathrm{g}$ wet weight, $P<0.01, n=4$ ) and poly-L-arginine $(0.5 \pm 0.2 \mathrm{pmol} / \mathrm{g}$ wet weight, $P<0.01, n$ $=4$ ) mediated CGRP-LI release (Fig. 6, $a$ and $b$ ).

\section{Discussion}

Tachykinins are a family of small peptides that have been localized to unmyelinated sensory $\mathrm{C}$-fibers in many organs, including the lung. These peptides have a variety of biological functions that may be important not only in the pathogenesis of bronchial asthma, but also in a variety of other airway inflammatory diseases (6). It is now becoming more apparent that there is a close interaction between inflammatory cells and sensory nerve activation, although the exact interrelationship is at present unknown.

We have reported previously that human eosinophil-derived MBP can increase airway responsiveness in vivo (13, $14)$, a property shared by synthetic cationic proteins $(13,14$, 18 ), and we have suggested that charge interactions are responsible for this phenomenon (14). In the present series of experiments, we have extended these observations and demonstrated that the ability of cationic proteins to induce airway hyperresponsiveness and plasma protein extravasation is dependent on activation of capsaicin-sensitive nerves.

Neonatal treatment of rats with capsaicin, which produces an irreversible degeneration of peptide-containing nerves in the airways (1), inhibited the development of airway hyperresponsiveness induced by synthetic cationic proteins. However, this method has the disadvantage that it is nonspecific, and other nonpeptide neurotransmitters present in afferent C-fibers may also be lost. Accordingly, we have used a second approach, the inhibition of neutral endopeptidase (NEP), an ecto-enzyme that has been demonstrated to modulate the physiological and pharmacological effects of tachykinins in vitro $(19,20)$ and in vivo $(21,22)$. Airway hyperresponsiveness induced by a submaximal dose of poly-L-lysine (13) was potentiated by the NEP inhibitor phosphoramidon, at a concentration that has been demonstrated previously to augment the effects of substance $P$ in vivo $(21,22)$. However, tachykinins are not the only substrate for this enzyme and other peptides are also degraded by NEP (23).

Thus, to address these limitations and to identify the specific neuropeptide involved in this phenomenon, we have used two nonpeptide antagonists for the NK-1 receptor CP-96,345 (15)

and RP-67580 (16). The most potent endogenous ligand for this receptor is substance $P$, with an affinity severalfold greater for the NK-1 receptor than for either neurokinin A or neurokinin B. Pretreatment with either CP-96,345 or RP-67580 at concentrations comparable to those used to selectively inhibit the effects of substance $P$ in the airways $(15,16,24,25)$, inhibited cationic protein-induced airway hyperresponsiveness. Thus, based on three separate experimental approaches, we have demonstrated that cationic proteins induce airway hyperresponsiveness dependent on activation of sensory C-fibers. Moreover, based on selective antagonist studies, a central role is proposed for substance $P$ in this phenomenon.

The hypothesis that stimulation of airway C-fibers is important in cationic protein-induced airway hyperresponsiveness is further supported by neurochemical data, demonstrating that cationic proteins can stimulate activation of sensory nerves in vitro, as assessed by the measurement of the overflow of CGRPLI. In these experiments, substance $P$ release was not measured directly, as levels of this peptide are some 10 times lower than those of CGRP in the airways (1). However, it has been established that substance $\mathrm{P}$ and CGRP are colocalized in sensory nerves $(26,27)$ and are coreleased upon neural activation (28). Thus, measurement of CGRP-LI release is a useful neurochemical marker for activation of sensory nerves and it is reasonable to assume that the release of CGRP is paralleled by substance $P$ release.

Cationic proteins were potent stimulators of sensory C- $\mathrm{fi}$ bers, releasing $\sim 20 \%$ of CGRP-LI induced by capsaicin, which is similar to that induced by other mediators such as bradykinin (29), histamine $(29,30)$, and lipoxin A4 (31). The kinetics of the release of CGRP between the two cationic proteins was different, however, in that poly-L-arginine induced a slowly developing, prolonged release of CGRP-LI, while poly-L-lysine induced a rapid and transient release. The reasons for this discrepancy is unclear, but may be related to technical difficulties of working with such highly charged cationic proteins, which bind readily to plastic surfaces and, hence, reduce the amount of free unbound protein in the perfusion system. Alternatively, this difference may be related to the density of charge between the two proteins.

Two independent processes for sensory peptide release have been identified to date. The first is activated by capsaicin and is $\omega$-conotoxin-resistant and ruthenium red-sensitive. The second mechanism is activated by electrical stimulation and is $\omega$ conotoxin-sensitive and ruthenium red-resistant (32). Whether the mechanism by which cationic proteins stimulate sensory nerves can be classified into these two groups requires further investigation. In addition to a direct effect on sensory nerve endings, cationic proteins may induce peptide release in part via the generation of other mediators. In this regard, we have reported recently that synthetic cationic proteins can activate kallikrein and induce the subsequent generation of bradykinin (18). Bradykinin is capable of stimulating peptide-containing nerves and has been demonstrated to induce substance $P$ release from perfused guinea pig airways (29). Whether bradykinin contributes to cationic protein-induced airway hyperresponsiveness by stimulating peptide release remains to be determined.

Substance $\mathrm{P}$ may contribute to cationic protein-induced airway hyperresponsiveness by a number of mechanisms including the induction of airway edema (3), stimulation of mucus secretion (5), and augmentation of cholinergic transmission 
(4). While we have not attempted to further investigate the underlying involvement of substance $P$, we have demonstrated that poly-L-lysine will induce plasma protein extravasation in the airways. Pretreatment with CP-96,345 inhibited poly-L-lysine-induced plasma protein extravasation throughout the airways, the exception being in the distal airways where no inhibition was observed. Such results are consistent with the lack of substance $\mathbf{P}$ immunoreactive nerves in the lower respiratory tract of rats (33). Similarly, tachykinin depletion has been demonstrated to inhibit increased vascular leakage induced by a variety of mediators and inflammatory stimuli including bradykinin, smoke, ozone, and formaldehyde (34). The relationship between airway edema and airway hyperresponsiveness are unclear at present. Certainly, loss of vascular integrity will provide a source of bioactive plasma-derived proinflammatory mediators, such as bradykinin and complement components. In addition, the formation of interstitial edema may modulate epithelial permeability as a result of increased hydrostatic pressure, thereby allowing greater amounts of the inhaled agonist to the underlying smooth muscle (35). In this context, we have demonstrated recently that cationic proteins can modulate epithelial function in vitro, by both inhibiting the release of an epithelialderived relaxant factor and modifying the barrier function of epithelium (36).

Activation of unmyelinated sensory C-fibers has also been implicated in airway hyperresponsiveness induced by allergen (7), PAF $(37,38)$, and toluene diisocyanate (39). Since provocation with these irritants is associated with the accumulation and activation of inflammatory cells, it is interesting to speculate that cationic proteins released from an array of cells including the eosinophil, neutrophil, and platelet may be responsible for activation of sensory C-fibers. In this regard, we have recently reported that in addition to MBP, neutrophil-derived cathepsin $\mathrm{G}$ and platelet-derived platelet factor 4 , are all capable of inducing airway hyperresponsiveness (14). It remains to be determined whether each of these proteins are also capable of inducing sensory nerve activation.

In summary, we have extended our previous observations and demonstrated that synthetic cationic proteins induce both airway hyperresponsiveness and plasma protein extravasation dependent on activation of capsaicin-sensitive sensory C-fibers. In particular, we propose a central role for substance $\mathrm{P}$, based on selective antagonist studies. Further investigations are required to delineate more precisely the mechanisms by which cationic proteins can stimulate sensory nerve activation. In addition, the exact contribution of substance $P$ to altered airway responsiveness after treatment with cationic proteins remains to be determined. However, our results suggest that cationic proteins may function as a link between airway inflammatory cell accumulation and sensory nerve activation.

\section{Acknowledgments}

We are very grateful to Elena Del Bianco for technical assistance, Dr. Claude Bertrand for helpful discussions, and Dr. John Stam and Pfizer Pharmaceutical Inc. for the generous gift of CP-96,345. 36577 .

This work was supported by National Institutes of Health grant HL-

\section{References}

1. Geppetti, P., S. Frilli, D. Renzi, P. Santicioli, C. A. Maggi, E. Theodorsson, and M. Fanciullacci. 1988. Distribution of calcitonin gene related peptide-like immunoreactivity in various rat tissues: correlation with substance $P$ and other tachykinins sensitive to capsaicin. Regul. Pept. 23:289-298.

2. Shore, S. A., and J. M. Drazen. 1991. Relative bronchoconstrictor activity of neurokinin A and neurokinin A fragments in the guinea pig. J. Appl. Physiol. 71:452-457.

3. Lundberg, J. M., E. Brodin, X. Hua, and A. Saria. 1984. Vascular permeability changes and smooth muscle contraction in relation to substance $P$ neurons with special reference to the trachea and lungs. Acta Physiol. Scand. 119:243252.

4. Tanaka, D. T., and M. M. Grunstein. 1986. Effect of substance $P$ on neurally mediated contraction of rabbit airway smooth muscle. J. Appl. Physiol. 60:458463.

5. Kuo, H-P., J. A. L. Rohde, K. Tokuyama, P. J. Barnes, and D. F. Rodgers. 1990. Capsaicin and sensory neuropeptides stimulation of goblet cell secretion in guinea pig trachea. J. Appl. Physiol. 431:629-641.

6. Barnes, P. J. 1989. New concepts in the pathogenesis of bronchial asthma. J. Allergy Clin. Immunol. 83:1013-1026.

7. Matsuse, T., R. J. Thompson, X-R. Chen, H. Salari, and R. R. Schellenburg. 1991. Capsaicin inhibits airway hyperresponsiveness, but not lipoxygenase activity or eosinophilia after repeated aerosolised antigen in guinea pigs. Am. Rev. Respir. Dis. 144:268-372.

8. Coyle, A. J., S. C. Urwin, B. Vilain, C. Touvay, C. P. Page, and P. Braquet. 1989. The effect of the selective PAF antagonist, BN 52021 on PAF and allergen induced bronchial hyperresponsiveness and eosinophil accumulation in the guinea pig. Eur. J. Pharmacol. 148:51-58.

9. Wardlaw, A. J., S. Dunette, G. J. Gleich, J. V. Collins, and A. B. Kay. 1988. Eosinophils in the bronchoalevolar lavage fluid in subjects with mild asthma. Am. Rev. Respir. Dis. 137:62-70.

10. Coyle, A. J., E. Coeffier, D. Joseph, V. Lagente, J. Lefort, and B. B. Vargaftig. 1991. Antigen challenge induces airway hyperresponsiveness in the guinea pig following transfer of eosinophils from sensitised animals. $\mathrm{Br}$. J. Pharmacol. 102:20P. (Abstr.)

11. Ackerman, S. J., D. A. Loegering, P. Venge, I. Olsson, J. B. Harley, A. S. Fauci, and G. J. Gleich. 1983. Distinctive cationic proteins of the human eosinophil granule: major basic protein, eosinophil cationic protein and eosinophil-derived neurotoxin. J. Immunol. 131:2977-2982.

12. Gundel, R. H., L. G. Letts, and G. J. Gleich. 1991. Human eosinophil major basic protein induces airway constriction and airway hyperresponsiveness in primates. J. Clin. Invest. 87:1470-1473.

13. Uchida, D. A., A. J. Coyle, S. J. Ackerman, P. F. Weller, G. L. Larsen, and C. G. Irvin. 1993. The effects of human eosinophil granule major basic protein on airways responsiveness in the rat in vivo: a comparison with polycations. Am. Rev. Respir. Dis. 147:982-988.

14. Coyle, A. J., S. J. Ackerman, and C. G. Irvin. 1993. Cationic proteins induce airway hyperresponsiveness dependent on charge interactions. Am. Rev. Respir. Dis. 147:896-900.

15. Snider, R. M., J. Constantine, J. A. Lowe, K. P. Lono, W. S. Lebel, H. A Woody, S. E. Droza, M. C. Desai, F. J. Vinick, R. W. Spencer, and H. J. Hess. 1991. A potent non peptide antagonist of the substance $P$ (NK-1 receptor). Science (Wash. DC). 251:435-439.

16. Garret, C., A. Carruette, V. Fardin, S. Moussaoui, J-F. Peyronel, J-C. Blanchard, and P. M. Laduron. 1991. Pharmacological properties of a potent and selective non peptide substance $\mathrm{P}$ antagonist. Proc. Natl. Acad. Sci. USA. 88:10208-10212.

17. Belvisi, M. G., D. F. Rodgers, and P. J. Barnes. 1989. Neurogenic plasma extravasation: inhibition by morphine in guinea pig airways in vivo. J. Appl. Physiol. 66:268-272.

18. Coyle, A. J., R. N. Burch, and C. G. Irvin. 1992. Synthetic cationic proteins induce airway hyperresponsiveness in vivo dependent on bradykinin generation. Am. Rev. Respir. Dis. 145:A38. (Abstr.).

19. Stimler-Gerard, N. P. 1987. Neutral endopeptidase-like enzyme controls the contractile activity of substance $\mathrm{P}$ in guinea pig lung. J. Clin. Invest. 79:18191825.

20. Martins, M. A., S. A. Shore, N. P. Gerard, C. Gerard, and J. M. Drazen 1990. Peptidase modulation of the pulmonary effects of tachykinins in tracheal superfused guinea pig lungs. J. Clin. Invest. 85:170-176.

21. Dusser, D. J., E. Umeno, P. D. Graf, T. Djokic, D. B. Borson, and J. A. Nadel. 1988. Airway neutral endopeptidase-like enzyme modulates tachykinin induced bronchoconstriction in vivo. J. Appl. Physiol. 65:2585-2591.

22. Borson, D. B., J. J. Brokaw, K. Sekizawa, D. M. McDonald, and J. A. Nadel. 1989. Neutral endopeptidase and neurogenic inflammation in rats with respiratory infections. J. Appl. Physiol. 66:2653-3658.

23. McKay, K. O., J. L. Black, and C. L. Amour. 1992. Phosphoramidon augments the contractile response to endothelin-3, but not endothelin-1 in isolated airway tissue. Br. J. Pharmacol. 105:929-932.

24. Bertrand, C., J. A. Nadel, I. Yamawaki, and P. Geppetti. 1993. Role of kinins in the vascular extravasation evoked by antigen and mediated by tachykinins in guinea pig trachea. J. Immunol. 151:4902-4907.

25. Bertrand, C., P. Geppetti, P. D. Graf, A. Foresi, and J. A. Nadel. 1993. 
Involvement of neurogenic inflammation in antigen induced bronchoconstriction in guinea pigs. Am. J. Physiol. 265:507-511.

26. Lundberg, J. M., J. C. Anders, X. Hua, T. Hokfelt, and J. A. Fischer 1985. Coexistance of substance $P$ and calcitonin related gene peptide-like immunoreactivity in sensory nerves in relation to cardiovascular and bronchoconstrictor effect of capsaicin. Eur. J. Pharmacol. 108:315-319.

27. Kroll, F., J. A. Karlsson, J. M. Lundberg, and C. G. A. Persson. 1990 Capsaicin induced bronchoconstriction and neuropeptide release in guinea pig perfused lungs. J. Appl. Physiol. 68:1679-1687.

28. Martling, C. R. 1987. Sensory nerves contain tachykinins and CGRP in the lower airways. Acta Physiol. Scand. 130(Suppl.):1-57.

29. Saria, A., C-R. Martling, Z. Yan, E. Theodorsson-Norheim, R. Gamse and J. M. Lundberg. 1988. Release of multiple tachykinin from capsaicin sensitive sensory nerves in the lungs by bradykinin, histamine, dimethylphenyl piperazinium and vagal stimulation. Am. Rev. Respir. Dis. 137:1330-1335.

30. Martins, M. A., S. Shore, and J. M. Drazen. 1991. Release of tachykinins by histamine, methacholine, PAF and substance P from guinea pig lungs. Am. J. Physiol. 261:449-455.

31. Meini, S., S. Evangelista, P. Geppetti, A. Szallasi, P. M. Blumberg, and S. Manzini. 1992. Pharmacological and neurochemical evidence for the activation of capsaicin sensitive sensory nerves by lipoxin A4 in guinea pig bronchus. Am. Rev. Respir. Dis. 146:930-934.

32. Maggi, C. A., R. Patacchini, P. Santicioli, S. Giuliani, E. Del Bianco, P. Geppetti, and A. Meli. 1989. The 'efferent' function of capsaicin sensitive nerves: ruthenium red discriminates between different mechanisms of activation. Eur. $J$. Pharmacol. 170:169-177.

33. Sertl, K., C. J. Wiedermann, M. L. Kowalski, S. Hurtado, J. Plutchok, I. Linnoila, C. B. Pert, and M. A. Kaliner. 1988. Substance P: the relationship between receptor distribution in rat lung and the capacity of substance $P$ to stimulate vascular permeability. Am. Rev. Respir. Dis. 138:151-159.

34. Lundberg, J. M., and A. Saria. 1983. Capsaicin induced desensitization of airway mucosa to cigarette smoke, mechanical and chemical irritants. Nature (Lond.). 302:251-253.

35. Kondo, M., W. E. Finkbeiner, and J. H. Widdicombe. 1992. Changes in permeability of dog trachea in response to hydrostatic pressure. Am. J. Physiol. 262:176-182.

36. Coyle, A. J., W. Mitzner, and C. G. Irvin. 1993. Cationic proteins alter smooth muscle function by an epithelial dependent mechanism. J. Appl. Physiol. 74:1761-1768.

37. Spina, D., M. G. McKenniff, A. J. Coyle, E. A. M. Seeds, M. Tramontana, F. Perretti, S. Manzini, and C. P. Page. 1991. The effect of capsaicin on PAF induced airway hyperresponsiveness and pulmonary cell accumulation in the rabbit. Br. J. Pharmacol. 103:1268-1274.

38. Perretti, F., and S. Manzini. 1993. Activation of capsaicin-sensitive sensory nerve fibres modulates PAF-induced bronchial hyperresponsiveness in anaesthetised guinea pigs. Am. Rev. Respir. Dis. 148:927-931.

39. Sheppard, D., and L. Scypinski. 1988. A tachykinin antagonist inhibits and an inhibitor of tachykinin metabloism potentiates toluene diisocyanate induced airway hyperresponsiveness in guinea pigs. Am. Rev. Respir. Dis. 138:547-551. 